\title{
Gambaran Pelaksanaan Serah Terima Antar Shift di Rumah Sakit X Jakarta
}

\author{
Amalia Cahyaningtyas ${ }^{1 *}$, Hanny Handayani ${ }^{2}$, Aat Yatnikasari ${ }^{3}$ \\ 1Postgraduate Student, Faculty of Nursing, Universitas Indonesia. *Email: amaliacahya.thesis@gmail.com \\ 2Department Basic Science \& Fundamental Nursing, Universitas Indonesia. \\ ${ }^{3}$ Nusing Care Quality Subcommitee RSAB Harapan Kita Jakarta.
}

\section{Abstract}

\section{A description of handover processes in hospital: A survey from Jakarta, Indonesia}

Background: Handover at the change of nurse shift is one of an important role in patient safety and continuiting quality of care.

Purpose: To optimization of implementation of handover processes in hospital: A survey from Jakarta, Indonesia Method: An analysis study with approach fishbone diagram, start with filling in questionnaires, observations and interviews and then analyzed using fishbone diagrams. Based on fishbone diagrams, the problem was obtained that the implementation of handover of patient patients was not optimal.

Results: To optimize the implementation of handover, implementation was carried out in the form of improving SPO, improving nurses' effective communication with SBAR and making role play video handover.

Conclusion: The result is the handover can be optimal with the role and function of management of the head nurse especially a directing role. Recommendations given by follow up and revising the hand over standars, make a pilot project nursing ward and evaluate the implementation of the patient's handover through regular supervision.

\section{Keywords: Fishbone Diagram; Handover; Head Nurse; Optimization; Directing}

Pendahuluan: Serah terima perawat antar shift jaga merupakan salah satu komponen penting dalam mencapai keselamatan pasien dan mempertahankan kualitas asuhan.

Tujuan: Meningkatkan optimalisasi fungsi pengarahan kepala ruang dalam pelaksanaan serah tertima antar shift di RS X Jakarta.

Metode: Menggunakan study analysis situasi dengan pendekatan diagram tulang ikan, dimulai dengan mengisi kuesioner, observasi dan wawancara dan kemudian dianalisis menggunakan diagram tulang ikan. Berdasarkan diagram tulang ikan, masalah diperoleh bahwa pelaksanaan serah terima pasien pasien belum optimal.

Hasil: Untuk mengoptimalkan pelaksanaan serah terima, implementasi dilakukan dalam bentuk meningkatkan SPO, meningkatkan komunikasi efektif perawat dengan SBAR dan membuat role play video serah terima.

Simpulan: Hasilnya adalah serah terima dapat dioptimalkan dengan peran dan fungsi manajemen kepala ruang khususnya fungsi pengarahan. Rekomendasi yang diberikan dengan menindaklanjuti dan merevisi SOP serah terima, membuat ruang percontohan dan mengevaluasi pelaksanaan serah terima pasien melalui pengawasan rutin.

\section{Kata Kunci: Diagram Tulang Ikan; Serah Terima; Kepala Ruang; Optimalisasi; Pengarahan}

\section{PENDAHULUAN}

Serah terima antar shift perawat yang efektif menjadi kunci dalam mempertahankan kualitas asuhan keperawatan yang baik. Proses serah terima merupakan proses transfer komunikasi antara perawat yang berdinas sebelumnya kepada perawat yang berdinas selanjutnya. Komunikasi yang terjadi pada proses perpindahan shift jaga ini merupakan upaya untuk mempertahankan asuhan keperawatan yang berkesinambungan (Julianto, \& Soelarto, 2016; Fernanda, 2019). Rumah Sakit sebagai fasilitas pelayanan kesehatan dituntut untuk dapat memberikan pelayanan yang berkualitas. UU Keperawatan No.38 tahun 2014 pada pasal 31 ayat 2 dijelaskan mengenai tugas perawat yang mengelola Pelayanan Keperawatan. Perawat berwenang untuk melakukan pengkajian dan menetapkan permasalahan; merencanakan, melaksanakan, dan mengevaluasi pelayanan keperawatan; dan c. mengelola kasus. Pernyataan ini sejalan dengan standar akrediasi SNARS pada Sasaran Keselamatan Pasien 2, elemen penilaian 2.2 menyebutkan bahwa rumah sakit harus memiliki regulasi tentang peningkatan komunikasi efektif 
antar profesional pemberi asuhan (PPA). Rumah sakit wajib mengembangkan dan menerapkan proses untuk komunikasi efektif melalui kegiatan serah terima sebagai wujud mempertahankan keselamatan pasien (Komisi Akreditasi Rumah Sakit, 2017).

Efektifitas serah terima antar shift bukan hanya dapat mengurangi resiko terjadinya insiden keselamatan pasien namun juga menjadi upaya untuk meningkatkan kualitas pelayanan yang ada. Perawat saling berkomunikasi dengan prinsip SBAR untuk mempertahankan kesesuaian informasi berdasarkan kondisi pasien yang menjadi tanggungjawabnya. Tindak lanjut dan kesinambungan pelayanan dan asuhan keperawatan menjadi point penting dalam kegiatan serah terima antar shift. Pelaksanaan serah terima dengan melibatkan pasien dan keluarga secara langsung di samping tempat tidur pasien memiliki dampak yang signifikasn dalam meningkatkan kualitas pelayanan. Pasien dan keluarga yang dilibatkan langsung merasa lebih diperhatikan dan meningkatkan perasaan otonomi atas program terapi yang diberikan (Oxelmark, et all., 2020; Smeulers, Lucas, \& Vermeulen, 2014)

Kepala ruang sebagai pimpinan dan manajer lini pertama memiliki peran dan fungsi yang sangat penting dalam mempertahankan kualitas pelayanan di unitnya. Fungsi manajemen kepala ruang salah satunya adalah fungsi pengarahan, karena fungsi pengarahan merupakan suatu proses penerapan perencanaan manajemen untuk mencapai tujuan perawatan. Pengarahan yang baik dapat menciptakan kerjasama yang efektif dan efisien antara staf. Pengarahan juga berfungsi untuk mengembangkan kemampuan dan ketrampilan staf khususnya dalam pelaksanaan serah terima antar shift (Pobas, Chrismilasari, \& Warjiman, 2018). Serah terima yang merupakan proses pengalihan wewenang dan tanggung jawab utama untuk memberikan perawatan klinis kepada pasien dari satu pemberi asuhan kepada pemberi asuhan yang lain untuk menjamin kontinuitas perawatan melalui proses pertukaran informasi dan transfer tanggungjawab atas perawatan pasien berpotensi lebih optimal dengan funsgi pengarahan dari kepala ruang (Ayala, 2017).

Regulasi yang berlaku di RS X Jakarta mengatur mengenai serah terima antar shift dalam bentuk standar operasional prosedur (SOP). SOP ini sendiri sampai dengan tahun 2019 telah mengalami revisi sebanyak empat kali. Berdasar hasil pengkajian awal yang dilakukan di RS X Jakarta selama bulan September hingga Oktober 2019 didapatkan bahwa pelaksanaan serah terima antar shift belum sepenuhnya berjalan sesuai SOP yang berlaku. Perawat masih terfokus pada pelaporan kondisi pasien secara umum dan belum spesifik merujuk pada asuhan keperawatan. Serah terima didominasi dengan pelaporan kondisi medis dan administratif pasien. Pelaksanaan serah terima dalam 30 menit, pelaksanaan serah terima langsung ke pasien dan komunikasi SBAR dalam serah terima belum konsisten dilaksanakan. Sebagai upaya optimalisasi serah terima diruangan, penulis menggunakan diagram Fishbone untuk mengetahui akar masalah belum optimalnya kualitas serah terima dipelayanan. Metode ini digunakan untuk menganalisa penyebab dari sebuah masalah atau kondisi.

\section{METODE PENELITIAN}

Metode yang digunakan berupa study analysis situasi dengan pendekatan diagram fishbone meliputi man, method, machine, material dan measurement. Identifikasi data awal dilaksanakan dengan kuesioner, observasi dan wawancara terhadap kepala ruangan, ketua tim dan perawat pelaksana terkait metode serah terima yang dilakukan di ruang rawat inap. Data yang ditemukan di analisis menggunakan diagram fish bone untuk memetakan dan menemukan masalah. Kemudian dilakukan penetapan prioritas masalah bersama kepala ruangan dan katim untuk menentukan strategi pemecahan masalah menggunakan siklus PDSA (Plan Do Study Action) (Pobas, Chrismilasari, \& Warjiman, 2018).

Selanjutnya dilakukan implementasi berupa sosialisasi dan diseminasi mengenai pelaksanaan serah terima yang optimal, evaluasi terhadap SPO yang telah dimiliki rumah sakit, menyusun panduan pelaksanaan komunikasi efektif dalam serah terima pasien, role play dan pembuatan video untuk memudahkan perawat memahami alur serah terima yang efektif. Evaluasi kegiatan dilakukan melalui observasi dan supervisi pelaksanaan serah terima antar shift keperawatan pada setiap pergantian shift keperawatan. Evaluasi dilakukan untuk mendapatkan hasil studi ini dapat diaplikasikan untuk kemudian dapat dijadikan rekomendasi dan rencana tindak lanjut bagi peningkatan kualitas pelaksanaan serah terima di Rumah Sakit X.

Amalia Cahyaningtyas"* Postgraduate Student, Faculty of Nursing, Universitas Indonesia.

*Email: amaliacahya.thesis@gmail.com

Hanny Handayani ${ }^{2}$ Department Basic Science \& Fundamental Nursing, Universitas Indonesia.

Aat Yatnikasari ${ }^{3}$ Nusing Care Quality Subcommitee RSAB Harapan Kita Jakarta. 


\section{HASIL}

Proses pengkajian awal terkait serah terima antar shift yang dilakukan di RS $X$ Jakarta meliputi observasi, wawancara dan pengambilan data dalam bentuk kuesioner penulis mendapatkan gamabran mengenai pelaksanaan serah terima yang sudah berjalan. Berdasarkan hasil observasi serah terima secara umum yang biasa dilaksanakan di awal proses serah terima yang dipimpin oleh kepala ruang beberapa kali tidak terlaksana. Hal ini terjadi khususnya pada serah terima antar shift pagi ke shift siang atau dari shift siag ke shift malam. Fungsi kepala ruang dinilai belum optimal khususnya yang berhubungan dengan peran kepala ruang sebagai figure head, dimana sosok kepala ruang bukan hanya dihormati ketika secara fisik ada di ruangan namun juga ketika kepala ruang tidak ada dan mendelegasikan tugasnya pada $\mathrm{PN}$ atau Katim (Pobas, Chrismilasari, \& Warjiman, 2018).

Perawat juga nampak belum konsisten dalam melaksanakan serah terima antar shift khususnya ketika harus melakukan serah terima di depan pasien. Hal tersebut nampak dari pasien yang tidak mengetahui siapa perawat yang bertanggung jawab terhadap proses perawatannya pada waktu dilakukan observasi. Salah satu hambatan yang muncul terkait dengan kepatuhan dan kedisipliknan perawat dalam kehadiran. Idealnya perawat dapat hadir 15 menit sebelum jam dinas, selain sebagai waktu untuk mempersiapkan diri sebelum serah terima waktu tersebut bisa digunakan untuk mengorientasikan kembali kondisi ruangan dan pasien. Adanya waktu untuk orientasi ini memungkinkan pemberian pelayanan yang berkesinambungan dari perawat. Sehingga asuhan yang telah diberikan tidak terputus dan terus menerus mengalami keberlanjutan (Tobiano, et all., 2018).

Penggunaan komunikasi SBAR dalam proses serah terima antar shift juga belum terlaksana secara optimal. Perawat belum secara konsisten dalam mengaplikasikan teknik komunikasi SBAR dalam pelaksanaan serah terima. Terkait kondisi diatas sangat berhubungan dengan pembelakuan SOP Serah Terima antar shift dimana penulis melihat pada SOP yang ada revisi ketiga yang dilakukan di tahun 2017 belum menyertakan komponen SBAR dalam serah terima. Ditemukan komponen komponen lain seperti kondisi medis, kondisi sarana prasarana dan kondisi administrtif yang lebih di tekankan. Revisi selanjutnya dilakukan pada tahun 2019, sudah memasukan komponen SBAR dalam SOP Serah Terima Antar Shift. Namun di dapatkan juga kondisi bahwa SBAR yang dimaksud belum dijelaskan secara terperinci. Sehingga memungkinakan munculnya multi tafsir dalam pelaksanaan serah terima. Hasil obeservasi ini didukung dengan hasil wawancara berupa focus group discussion menyatakan selama ini serah terima antar shift perawat berjalan belum sesuai dengan SOP yang ada.

Fokus diskusi selanjutnya adalah mendiskusikan form serah terima yang selama ini berlaku di RS $X$ Jakarta. Penggunaan formulir serah terima pasien mendapatkan 2 pendapat. Ada yang berpendapat penggunaan formulir serah terima merupakan pemborosan selain menambah jumlah penggunaan kertas dalam rekam medis pasien dan menambah tanggung jawab pencatatan dokumentasi. Semua informasi terkait kondisi pasien yan di operkan sudah tertulis dan tergambar dengan lengkap pada lembar CPPT. Pendapat lain menyatakan karena sekaraang pencatatan CPPT menggunakan SIM RS yang menyulitkan kalau digunakan operan, maka lembar serah terima yang disediakan cukup membantu dan efektif. Pernyataan kedua ini berkaitan dengan pemberlakuan SIM RS yang belum menyeluruh, sebagian berkas pasien sudah bermigrasi ke SIM RS sedangkan sebagian berkas lainnya masih manual. Sehingga penggunaan form serah terima ini dirasa cukup membantu. Hasil pengkajian data awal ini diperkuat dengan hasil data dari kuesioner yang diisi oleh 140 perawat, baik kepala ruang, PN, Katim maupun perawat pelaksana. Hasil data kuesioner didapatkan sebagai berikut;

\footnotetext{
Amalia Cahyaningtyas'* Postgraduate Student, Faculty of Nursing, Universitas Indonesia.

${ }^{*}$ Email: amaliacahya.thesis@gmail.com

Hanny Handayani ${ }^{2}$ Department Basic Science \& Fundamental Nursing, Universitas Indonesia.

Aat Yatnikasari ${ }^{3}$ Nusing Care Quality Subcommitee RSAB Harapan Kita Jakarta.
} 
Tabel. Hasil Pengkajian Data Kuesioner

\begin{tabular}{|c|c|c|c|c|}
\hline \multirow[t]{2}{*}{ Indikator } & \multicolumn{4}{|c|}{ Hasil (dalam \%) } \\
\hline & Selalu & Sering & $\begin{array}{l}\text { Kadang } \\
\text { kadang }\end{array}$ & Tidak pernah \\
\hline $\begin{array}{l}\text { Sebelum serah terima perawat dinas sebelumnya menyiapkan } \\
\text { berkas rekam medis pasien }\end{array}$ & 64,3 & 22,9 & 10,0 & 2,9 \\
\hline Kedua shift jaga sudah dalam keadaan siap? & 59,3 & 32,9 & 7,1 & 0,7 \\
\hline $\begin{array}{l}\text { Serah Terima dipimpin oleh kepala ruangan pada pergantiar } \\
\text { shift dari malam ke pagi dan pagi ke sore }\end{array}$ & 43,6 & 35,7 & 17,9 & 2,9 \\
\hline $\begin{array}{l}\text { Serah Terima dilaksanakan selalu saat pergantian shift selama } \\
30 \text { menit }\end{array}$ & 37,9 & 39,3 & 22,1 & 0,7 \\
\hline Pelaksanaan serah terima dimulai di nurse station & 59,3 & 24,3 & 10,0 & 6,4 \\
\hline Perawat primer melaporkan kondisi ruangan secara umum & 63,6 & 25,0 & 7,9 & 3,6 \\
\hline $\begin{array}{l}\text { Pelaksanaan serah terima antar perawat assosiate dilaksanakar } \\
\text { dengan menggunjungi pasien }\end{array}$ & 65,0 & 22,9 & 7,9 & 4,3 \\
\hline $\begin{array}{l}\text { Perawat memperkenalkan diri, melakukan identifikasi pasien: } \\
\text { resiko jatuh, alergi dan menanyakan keluhan pasien }\end{array}$ & 65,7 & 30,0 & 4,3 & 0 \\
\hline $\begin{array}{l}\text { Perawat melaporkan kondisi pasien pada shift jaga berikutnye } \\
\text { dengan metode SBAR }\end{array}$ & 67,9 & 25,7 & 6,4 & \\
\hline $\begin{array}{l}\text { Perawat menunjukan akses, alat yang terpasang, lama alat } \\
\text { terpasang, kondisi luka, cairan/darah yang sedang diberikan }\end{array}$ & 59,3 & 27,9 & 11,4 & 1,4 \\
\hline $\begin{array}{l}\text { Perawat yang akan berdinas mencatat hal - hal penting dan nila } \\
\text { kritis di lembar serah terima yang sudah disediakan }\end{array}$ & 84,3 & 12,1 & 2,9 & 0,7 \\
\hline $\begin{array}{l}\text { Kedua perawat yang memberikan tanda tangan pada lembal } \\
\text { serah terima }\end{array}$ & 87,1 & 8,6 & 2,1 & 2,1 \\
\hline
\end{tabular}

Berdasarkan data dari kuesioner tabel didapatkan bahwa pelaksanaan serah terima antar shift belum terlaksana dengan baik. Perawat belum konsisten dalam melaksanakan langkah - langkah pelaksanaan serah terima antar shift sesuai dengan SOP yang berlaku.

\section{PEMBAHASAN}

Serah terima antar shift keperawatan adalah fase penting dalam proses perawatan pasien karena menyangkut dengan kompetensi perawat dalam mempertahankan asuhan keperawatan yang efektif dan melindungi keselamatan pasien. Komunikasi SBAR sebagai point penting dalam serh terima juga menjadi perhatian bagi pelaksanaan serah terima yang optimal. Kepala ruangan seharusnya memiliki peran yang sangat kuat dalam melakukan pengarahan terkait kegiatan yang dilakukan sebagai bentuk pengarahan terhadap kualitas layanan di unit yang dipimpin (Oxelmark, et all., 2020).

Analisis diagram fishbone dilakukan dalam hal menilai kualitas serah terima yang dilakukan perawat agar optimal dalam meningkatkan status derajat kesehatan pasien, sehingganya serah terima masuk dalam capaian kontrak kinerja bidang pelayanan keperawatan (Irena, 2017).
RS X merupakan rumah sakit kelas A sebagai pusat rujukan berlokasi di Jakarta, telah mendapatkan sertifikasi JCI dan KARS pada tahun 2018. Dengan predikatnya yang telah tersertifikasi diharapkan optimal dalam memberikan pelayanan yang berorientasi pada pasien (patient center care). Oleh karenanya banyak perubahan yang dilakukan demi meningkatkan mutu layanan asuhan sesuai visi misi rumah sakit. Salah satu upaya yang dapat dilakukan adalah dengan mengoptimalkan pelaksanaan serah terima antar shift jaga (Faisal, Syahrul, \& Jafar, 2019).

Adapun fungsi manajemen yang digunakan dalam mengoptimalkan serah terima menurut Wijaya, \& Rifa'i, (2016) adalah: Perencanaan adalah fungsi dasar dan pertama dalam manajemen (the first function of management). Semua fungsi manajemen tergantung dari perencanaan. Perencanaan adalah suatu proses berpikir atau proses mental untuk membuat keputusan dan perkiraan (forecasting). Perencanaan harus berorientasi ke masa depan dan memastikan kemungkinan hasil yang diharapkan. Salah satu hal penting yang menjadi pusat perhatian adalah rencana pengaturan sumber daya manusia (SDM) dan sumber daya yang lain yang relevan.

Amalia Cahyaningtyas'* Postgraduate Student, Faculty of Nursing, Universitas Indonesia.

*Email: amaliacahya.thesis@gmail.com

Hanny Handayani ${ }^{2}$ Department Basic Science \& Fundamental Nursing, Universitas Indonesia.

Aat Yatnikasari ${ }^{3}$ Nusing Care Quality Subcommitee RSAB Harapan Kita Jakarta. 
Perencanaan yang baik akan meningkatkan capaian tujuan dan pembiayaan yang efektif. Pengorganisasian adalah pengelompokan sejumlah aktivitas untuk mencapai tujuan yang diharapkan. Penugasan pada masing-masing kelompok dilakukan berdasarkan supervisi, ada koordinasi dengan unit lain baik secara horizontal maupun secara vertikal. Hal ini telah dijalankan di RSF dimana duty nurse selaku perpanjangan tangan dari bidang perawatan melalui bagian monitoring telah melakukan supervisi dan audit. Penempatan (Staffing) adalah Penyusunan yang tepat akan menyebabkan pelaksanaan kegiatan berlangsung baik, sehingga akan memudahkan seseorang untuk mencapai tujuan yang telah ditetapkan. Penempatan leadership dan komposisi tim menjadi tangung jawab kepala ruang dan PN, dimana leader yang akan memimpin serah terima pada setiap periode jaga perawat. Pengarahan (Actuating) atau disebut juga penggerakan merupakan upaya mempengaruhi staf agar melakukan sesuatu untuk mencapai tujuan yang telah ditetapkan, agar dapat mengarahkan dan menggerakan bawahan maka ada beberapa unsur yang perlu dipahami dan diperhatikan oleh manajer keperawatan adalah: Kepemimpinan, Motivasi, Komunikasi.

Pengendalian adalah proses untuk memastikan bahwa aktivitas yang dilakukan adalah sesuai dengan aktivitas yang direncanakan dan berfungsi untuk menjamin mutu serta evaluasi kinerja. Kerr, et all., (2016) menyampaikan pengendalian dalam manajemen adalah usaha sistematis untuk menetapkan standar prestasi kerja agar sesuai dengan tujuan perencanaan, untuk mendesain sistem umpan balik informasi, untuk membandingkan prestasi yang sesungguhnya dengan standar yang telah ditetapkan, untuk menetapkan apakah ada deviasi dan untuk mengukur signifikansinya, serta mengambil tindakan yang diperlukan untuk memastikan bahwa sumber daya digunakan dengan cara yang efektif dan efisien mungkin untuk mencapai tujuan. Pengendalian telah dilakukan namun belum mencapai target dan kualitas dari serah terima belum nampak terlihat dari data yang didapatkan dari hasil dokumentasi dan isi operan adanya pasien yang batal operasi karena tidak optimal dalam operan.Studi ini juga memperlihatkan kemampuan perawat dalam melakukan serah terima bersama pasien meningkat dalam banyak aspek seperti memperkenalkan perawat yang akan bertugas $(66,6 \%)$, melakukan komunikasi terapeutik
$(88,8 \%)$, melibatkan pasien $(66,2 \%)$. Standar SNARS 2018 mengungkapkan bahwa serah terima pasien bila memungkinkan maka dilakukan dengan melibatkan pasien, demikian juga dengan penelitian terkait pengenalan "patient centre care" dalam serah terima pasien, terjadi perubahan dalam kepuasan pasien berupa pertukaran informasi antara pasien dan perawat. Pasien dari bangsal intervensi memiliki skor secara statistik lebih tinggi setelah penerapan serah terima bersama pasien bila dibandingkan dengan bangsal kontrol ( $p=0,0058$ ). (Tobiano, Bucknall, Sladdin, Whitty, \& Chaboyer, 2018).

\section{Komunikasi Efektif dalam Serah Terima}

Salah satu alat yang banyak direkomendasikan dalam komunikasi dalam serah terima adalah SBAR (Situation, Background, Assesment dan Recommendation). Komunikasi informasi yang akurat pada pergantian shift adalah salah satu fungsi utama hand over untuk memastikan transisi yang aman bagi pasien saat tanggung jawab asuhan pasien bergeser dari tim sebelumnya ke tim berikutnya (Stensmyr, et all., 2012).

Selain itu, SBAR dapat memperjelas empat tema komunikasi formal: Peningkatan komunikasi; peningkatan transfer informasi; meningkatkan kepercayaan diri; dan meningkatkan keselamatan pasien (Superville, 2017). Komunikasi SBAR yang dilakukan oleh perawat di RS X sebesar 44,50\% dirasakan masih belum optimal pelaksanaannya sehingga diperlukan strategi baru. Serah terima antar shift dengan menggunakan metode SBAR sudah diimplementasikan hampir diseluruh rumah sakit. Berdasarkan hasil wawancara yang dilakukan peneliti di salah satu Rumah Sakit di Jakarta pada bulan November 2019 didapatkan bahwa informan setuju bahwa proses serah terima antar shift harus dilakukan dengan metode SBAR untuk mengoptimalkan pelayanan keperawatan dan sebagai bentuk upaya mencapai keselamatan pasien.

Metode SBAR yang sudah digunakan dalam serah terima antar shift cenderung lebih berfokus pada terapi - terapi medis, komplain pasien dan masalah administratif (Astuti, \& Ilmi, 2019). Pelaksanaannya belum merujuk pada asuhan keperawatan sebagai dasar keilmuan dan profesi perawat. Berdasarkan studi literatur yang dilakukan belum ada peneliti yang mengangkat fenomena terkait serah terima yang berfokus pada asuhan keperawatan. Studi Fenomenologi yang dilakukan di

Amalia Cahyaningtyas"* Postgraduate Student, Faculty of Nursing, Universitas Indonesia.

*Email: amaliacahya.thesis@gmail.com

Hanny Handayani ${ }^{2}$ Department Basic Science \& Fundamental Nursing, Universitas Indonesia.

Aat Yatnikasari ${ }^{3}$ Nusing Care Quality Subcommitee RSAB Harapan Kita Jakarta. 
salah satu rumah sakit di Indonesia menyimpulkan adanya perbedaan persepsi, sosialisasi SBAR sudah optimal, motivasi belum optimal adanya dampak positif pelaksanaan SBAR dan adanya resiko tidak terlaksananya SBAR saat serah terima (Dewi, Rezkiki, \& Lazdia, 2019).

Dari studi fenomenologi diatas juga belum nampak fokus pada asuhan keperawatan padahal sampel dan proses serah terima yang diambil adalah pelayanan keperawatan. Penerapan asuhan keperawatan dalam serah terima antar shift belum kontinyu dilakukan dalam pelayanan keperawatan. Pemahaman konsep asuhan keperawatan dapat merangkum seluruh kebutuhan pasien dalam pelaksanaan proses keperawatan. Kekuatan utama dari serah terima antar shift adalah kompetensi perawat dalam memahami masalah dan menentukan asuhan keperawawatan secara berkelanjutan pada pasien - pasien yang ditangani (Hada, Jack, \& Coyer, 2019).

Pengembangan kemampuan konstekstual yang dikomunikasikan menentukan intervensi keperawatan menjadi hal yang mendasar dalam penerapan serah terima antar shift. Upaya pengembangan metode serah terima yang sudah ada selama ini menjadi sebuah tantangan besar dalam pencapaian keselamatan pasien (Kerr, Klim, Kelly, \& Mccann, 2019).

\section{SIMPULAN}

Secara umum pelaksanaan serah terima antar shift jaga belum optimal, berdasarkan data audit serah terima yang dilakukan pada kepala ruang, PN , Katim dan perawat pelaksana angkanya masih berada dibawah $60 \%$. Serah terima perawatan adalah salah satu prosedur yang paling berbahaya jika tidak dilakukan dengan profesional dapat menjadi faktor utama penyumbang terjadinya kesalahan dan penundaan pelayanan berikutnya pada pasien (Safrina, \& Rahmah, 2019; Nopriyanti, \& Hariyati, 2017).

Perawat sebagai profesional pemberi asuhan diharapkan dapat mengoptimalkan serah terima. Pelaksanaan peran dan fungsi manajemen dari kepala ruang, staf keperawatan perlu mendapat dukungan dari berbagai pihak termasuk serah terima antar shit yang merupakan bagian dari asuhan keperawatan. Dukungan pihak manajemen yang melakukan audit dalam kontrak kinerjanya dirasa mampu mengoptimalkan baiknya mutu serah terima dalam memberikan asuhan keperawatan kepada pasien dan keluarga. Serah terima yang baik tidak terjadi secara kebetulan diperlukan kerjasama tim oleh semua pihak yang terlibat, koordinasi yang baik pada shift jaga perawat, waktu yang adekuat saat serah terima, leader yang jelas dan kompeten saat serah terima, kepatuhan perawat dalam ketepatan waktu pelaksanaan dan dukungan teknologi informasi yang memadai harus disediakan serta adanya pelatihan yang dapat meningkatkan mutu dari serah terima dan didukung oleh manajemen rumah sakit sebagai program peningkatan kualitas mutu asuhan yang memperhatikan continunm of care (Sutrisari, 2018).

Melihat hal tersebut perlu dilakukannya uji coba terhadap teknik pelaksanaan serah terima antar shift sebagai bentuk tindak lanjut. Kegiatan tersebut bertujuan untuk mengarahkan perawat pada perubahan sikap mengingat merubah pola perilaku yang sudah menjadi suatu kebiasaan merupakan proses yang singkat.

Mengambil ruang percontohan dengan dilibatkan secara aktif dalam pelaksanaan serah terima antar shift disusun dengan harapan untuk optimalisasi pelaksanaan serah terima antar shift keperawatan di RS X, hasil yang didapatkan hendaknya menjadi gambaran megenai pelaksanaan serah terima di RS $X$ dan dapat melakukan tindak lanjut berupa melakukan perencanaan bersama dengan komite keperawatan untuk revisi SOP AP serah terima antar shift dengan memasukkan komunikasi SBAR yang lebih berfokus pada asuhan keperawatan dan mengkaji kembali penggunaan form serah terima sebagai bukti serah terima. Pelayanan keperawatan yang optimal senantiasa mengedepankan mutu dan keselamatan pasien mampu tercipta melalui kegiatan ini.

\section{DAFTAR PUSTAKA}

Astuti, N., \& IImi, B. (2019). Penerapan Komunikasi Situation, Background, Assesment, Recomendation (SBAR) Pada Perawat Dalam Melaksanakan Handover. IJNP (Indonesian Journal of Nursing Practices), 3(1), 42-51.

Ayala, W. L. (2017). Impact of a Standardized Tool on Handoff Quality in Nurse Change-of-Shift Reports.

Amalia Cahyaningtyas"* Postgraduate Student, Faculty of Nursing, Universitas Indonesia.

*Email: amaliacahya.thesis@gmail.com

Hanny Handayani ${ }^{2}$ Department Basic Science \& Fundamental Nursing, Universitas Indonesia.

Aat Yatnikasari ${ }^{3}$ Nusing Care Quality Subcommitee RSAB Harapan Kita Jakarta. 
Dewi, R., Rezkiki, F., \& Lazdia, W. (2019). Studi Fenomenology Pelaksanaan Handover Dengan Komunikasi SBAR. Jurnal Endurance, 4(2), 350-358.

Faisal, F., Syahrul, S., \& Jafar, N. (2019). Pendampingan Hand Over Pasien Dengan Metode Komunikasi Situation, Background, Assesment, Recommendation (Sbar) Pada Perawat Di Rsud Barru Kabupaten Barru Sulawesi Selatan. Jurnal Terapan Abdimas, 4(1), 43-51.

Fernanda, Y., \& Amalia, N. E. (2019). Pelaksanaan operan keperawatan menggunakn teknik komunikasi SBAR di ruang Azzahrawi RSI Yarsi Bukittinggi tahun 2019 (Doctoral dissertation, Stikes Perintis Padang).

Hada, A., Jack, L., \& Coyer, F. (2019). Using a knowledge translation framework to identify barriers and supports to effective nursing handover: A focus group study. Heliyon, 5(6), e01960.

Irena, R. (2017). Hubungan Motivasi Dengan Kinerja Perawat Di Ruang Rawat Inap Rsud Dr. Rm Pratomo Bagansiapapi Tahun 2017. Prepotif: Jurnal Kesehatan Masyarakat, 1(2), 18-26.

Julianto, M., \& Soelarto, R. S. U. P. (2016). Peran dan Fungsi Manajemen Keperawatan dalam Manajemen Konflik. Jurnal Rumah Sakit Fatmawati.

Kerr, D., Klim, S., Kelly, A. M., \& McCann, T. (2016). Impact of a modified nursing handover model for improving nursing care and documentation in the emergency department: A pre-and post-implementation study. International journal of nursing practice, 22(1), 89-97.
Marquis, B. L., Huston, C. J., \& Propst, J. (2013). Leadership roles and management functions in nursing: Theory and application. Journal for Nurses in Professional Development, 8(6), 284287.

Nopriyanti, D., \& Hariyati, R. T. S. (2017). Optimalisasi Pelaksanaan Timbang Terima Dalam Metode Asuhan Keperawatan Dengan Model Tim: Pilot Study. Holistik Jurnal Kesehatan, 11(1), 14-22.

Oxelmark, L., Whitty, J. A., Ulin, K., Chaboyer, W., Gonçalves, A. S. O., \& Ringdal, M. (2020). Patients prefer clinical handover at the bedside; nurses do not: evidence from a discrete choice experiment. International journal of nursing studies, 105, 103444.

Pobas, S., Chrismilasari, L. A., \& Warjiman, W. (2018). Evaluasi Timbang Terima Pasien Oleh Perawat Di Ruang Rawat Inap Rumah Sakit. Jurnal Keperawatan Suaka Insan (Jksi), 3(2), 1-9.

Safrina, N., \& Rahmah, S. (2019). Optimalisasi Pelaksanaan Serah Terima Pasien Antar Shift Keperawatan di Ruang Rawat Inap Dewasa Rumah Sakit X Jakarta: Pilot Study. J. Kesehat. Almuslim [Internet], 4(8), 30-6.

Smeulers, M., Lucas, C., \& Vermeulen, H. (2014). Effectiveness of different nursing handover styles for ensuring continuity of information in hospitalised patients. Cochrane Database of Systematic Reviews, (6).

Stensmyr, M. C., Dweck, H. K., Farhan, A., Ibba, I., Strutz, A., Mukunda, L., \& Wicher, D. (2012). A conserved dedicated olfactory circuit for detecting harmful microbes in Drosophila. Cell, 151(6), 1345-1357.

Amalia Cahyaningtyas"* Postgraduate Student, Faculty of Nursing, Universitas Indonesia.

*Email: amaliacahya.thesis@gmail.com

Hanny Handayani ${ }^{2}$ Department Basic Science \& Fundamental Nursing, Universitas Indonesia.

Aat Yatnikasari ${ }^{3}$ Nusing Care Quality Subcommitee RSAB Harapan Kita Jakarta. 
Superville, J. (2017). Standardizing Nurse-to-Nurse Patient Handoffs in a Correctional Healthcare setting: a Quality Improvement Project to improve end-of-shift Nurse-to-Nurse Communication using the SBAR I-5 Handoff Bundle.

Sutrisari, S. N. (2018). Pengalaman Perawat Dalam Melaksanakan Komunikasi Efektif: Sbar (Situation, Background, Assesment Recommendation) Di Ruang Rawat Inap Flamboyan Rumah Sakit Pusri Palembang (Doctoral dissertation, Universitas Andalas).
Tobiano, G., Bucknall, T., Sladdin, I., Whitty, J. A., \& Chaboyer, W. (2018). Patient participation in nursing bedside handover: a systematic mixedmethods review. International journal of nursing studies, 77, 243-258.

Wijaya, C., \& Rifa'i, M. (2016). Dasar-dasar manajemen: mengoptimalkan pengelolaan organisasi secara efektif dan efisien.

Amalia Cahyaningtyas** Postgraduate Student, Faculty of Nursing, Universitas Indonesia.

*Email: amaliacahya.thesis@gmail.com

Hanny Handayani ${ }^{2}$ Department Basic Science \& Fundamental Nursing, Universitas Indonesia.

Aat Yatnikasari ${ }^{3}$ Nusing Care Quality Subcommitee RSAB Harapan Kita Jakarta. 